\begin{tabular}{lc}
\hline & ANNALES \\
& UNIVERSITATIS MARIAE CURIE-SKLODOWSKA \\
LUL.V & SECTIO N \\
\hline
\end{tabular}

ISSN: 2451-0491 • e-ISSN: 2543-9340 • CC-BY 4.0 • DOI: 10.17951/en.2020.5.83-99

\title{
Nurt antropocentryczno-kulturowy w dydaktyce literatury a współczesne antropologie
}

\section{Anthropocentric and Cultural Trend in Didactic Literature and Contemporary Anthropology}

\author{
Ewa Ogłoza \\ Uniwersytet Śląski. Wydział Humanistyczny \\ pl. Sejmu Śląskiego 1, 40-032 Katowice, Polska \\ ewa.ogloza@us.edu.pl \\ https://orcid.org/0000-0001-6524-0054
}

\begin{abstract}
The article discusses the anthropocentric and cultural trend in Polish language didactics (starting from Jan Polakowski). The author also points to a different understanding of the terms anthropology and anthropocentrism in modern humanities and gives examples of texts (of which even fragments are worth reading with students), questions that can be asked to students, and issues that students should be sensitive to - in connection with the presence in the literature, art and didactics of motives, plots and reflection of anthropological nature. The study is a kind of guide to selected issues and dissertations.
\end{abstract}

Keywords: anthropology; anthropocentrism; Polish language didactics; student; literature

Abstrakt. W artykule został omówiony nurt antropocentryczno-kulturowy w dydaktyce polonistycznej (począwszy od Jana Polakowskiego). Autorka wskazuje również na różne rozumienie terminów antropologia i antropocentryzm we współczesnej humanistyce oraz podaje przykłady tekstów, których nawet fragmenty warto czytać z uczniami, oraz pytań, które można stawiać uczniom, a także kwestii, na które powinno się uczniów uwrażliwiać w związku z obecnością 
w literaturze pięknej, sztuce i dydaktyce motywów, wątków i refleksji natury antropologicznej. Opracowanie stanowi rodzaj przewodnika po wybranych zagadnieniach i rozprawach.

Słowa kluczowe: antropologia; antropocentryzm; dydaktyka polonistyczna; uczeń; literatura

Artykuł składa się z dwóch części. Pierwsza ma charakter przewodnika zagadnieniowo-bibliograficznego, w którym znalazły się zwięzłe omówienia (przypomnienia) ważnych tekstów teoretycznych z różnych dyscyplin humanistycznych, w tym z zakresu dydaktyki polonistycznej. Druga natomiast zawiera kilka przykładów tekstów kultury współczesnej, które można i warto uwzględnić w szkolnej praktyce polonistycznej, dobierając odpowiednie do tematu i zespołu uczniowskiego aktywizujące metody dydaktyczne.

Antropologia wyrasta z zainteresowania człowiekiem - jednostki i wspólnoty, doświadczania siebie samego i rzeczywistości. Stawia pytania o to, kim jest człowiek i w jaki sposób żyje, w jakim stopniu integruje sfery: myślenia, przeżycia i działania (zob. Filipowicz 2012: 44-56), a także o to, jak zbudowane jest społeczeństwo i co oznacza słowo my. Dostrzega różnorodność i wspólne składniki (zob. EASA 2015), rozwija wyobraźnię intelektualną i moralną, pokazuje sieć relacji między ludźmi. Ponadto antropologia uczestniczy w „długiej rozmowie o człowieczeństwie”; to nie tylko „najbardziej naukowa gałąź humanistyki i najbardziej humanistyczna z nauk. Antropologia to także najpożyteczniejsza z nauk podstawowych" (tamże).

Jarema Drozdowicz (2018: 136), którego interesuje edukacja i wielokulturowość, pisze o takich dyscyplinach, jak antropologia społeczna i kulturowa oraz etnologia i etnografia. Dostrzegł w nich zainteresowanie procesem enkulturacji, czyli „kulturowego dojrzewania i nabywania nowych kompetencji”, dlatego połączył myśl antropologiczną ze studiami nad edukacją. Zaobserwował też takie zjawiska, jak skrajna indywidualizacja życia, tożsamościowy egocentryzm oraz partykularyzacja i fragmentaryzacja, a w związku z Innym i wielokulturowością (nie tylko multikulturalizmem czy polityczną poprawnością, lecz raczej codziennym doświadczaniem wielokulturowości) występują m.in. zwrot konserwatywny, ksenofobia, separatyzm, rasizm, kryzys społecznego zaufania oraz antyimigranckie postawy w opozycji do demokracji, prawa do wolności wyznania i sumienia, pluralizmu i równości wobec prawa. Jak zauważa autor, „rzeczywistość wielokulturowa ewoluowała, a wraz z nią polityka multikulturalizmu" (tamże: 147).

Marcin Gołębniak (2017: 45-60) początek antropologii edukacyjnej - jako subdyscypliny antropologii kulturowej - dostrzega w latach 50. XX wieku w USA. Odróżnia etnografię edukacyjną od etnografii edukacji. Antropologię edukacyjną i wchodzącą w jej skład etnografię edukacyjną można zaliczyć - w aspekcie tego 
rodzaju podejścia w praktykowaniu dyscypliny - zarówno do antropologii domowej, jak i do antropologii jako kulturowej krytyki. Poza charakterystyczną dla amerykańskiego wariantu dyscypliny różnorodnością kulturową, akcentowaną w opracowaniach z tego zakresu, pochodząca z teorii krytycznych inspiracja, tak w wyborze pola poszukiwań badawczych, jak i interpretacji oraz sposobów teoretyzowania wyników badań, jest nadto widoczna. Trzy najważniejsze szkoły myślenia w tym zakresie, obecne w pracach wielu autorów, to tzw. szkoła frankfurcka, związany z Paryskim Instytutem Etnologicznym francuski surrealizm oraz amerykańska szkoła krytyki dokumentalnej.

O antropologicznej teorii dydaktycznej (ATD) pisały m.in. Eliza Rybska i Zofia Sajkowska (2015), posługując się pojęciem transpozycji dydaktycznej (za rozprawą Yvesa Chevallarda z 1985 roku) i proponując metody dochodzenia do wiedzy, m.in. poprzez stawianie pytań (Questioning the World; inquiry based methods). W prakseologicznym modelu 4T wymieniają blok teoretyczny (czyli teorię i technologię - know that and why) oraz blok praktyczny (technikę i typ zadania - know how). Odnosząc to do nauczania literatury, można by mówić o: 1) zadaniach - pytaniach o składniki tekstu (zwłaszcza o elementy świata przedstawionego) oraz technikach (przede wszystkim o umiejętności czytania ze zrozumieniem); 2) technologii refleksyjnym, analityczno-interpretacyjnym podejściu do czytanych tekstów; 3) teorii - budowaniu odpowiedzi na pytanie, czym jest dzieło literackie.

$\mathrm{Na}$,antropologiczny potencjał rozwiązywania problemów społecznych” zwrócił uwagę m.in. Mateusz Sikora (2017: 143-167), wskazując na takie działania w pracy, jak eksperckie analizy, marketing, animacja kulturalna, raportowanie czy ewaluacja, a także na odpowiednie do tego typu działań cechy intelektualne, interpersonalne czy znajomość narzędzi badawczych.

Warto przypomnieć, co proponował nauczycielom znany pedagog Carl Rogers w 1994 roku. Chodzi o pytania do samooceny, czy potrafi się pomagać uczniom i studentom w uczeniu się, czyli o pytania typowe dla pedagogiki humanistycznej, skoncentrowanej na osobie (zob. np. Sajdak-Burska 2017: 16). Nauczyciel, który sam przeszedł proces odkrywania siebie samego oraz siebie $\mathrm{w}$ relacjach z innymi, ma szansę stać się gotowym do zaakceptowania drugiego (np. studenta) takim, jakim on jest, do obdarzenia go wolnością i zaufaniem.

Hana Červinkovà (2012: 7-18) wymienia w zaangażowanej antropologii: antropologię postkolonialną, ekologiczną, feministyczną i edukacyjną. Wysoko ocenia połączenie antropologii edukacyjnej i badań edukacyjnych w działaniu, ponieważ wykorzystuje się wtedy myślenie krytyczne i działanie uczestniczące (np. projektowanie zajęć lekcyjnych), rozwijając w ten sposób człowieczeństwo. Autorka prowadziła wraz z uniwersytecką koleżanką badania dotyczące przygotowania nauczycieli do pracy, odwołując się do etnografii edukacyjnej 
i badań w działaniu. Studentki dwukrotnie wypełniały dzienniczki obserwacji lekcji; dopiero za drugim razem opis był "gęsty”, wypełniony szczegółami tak, aby przedstawić zdarzenie komuś, kto tego nie widział. Opisy cechowały: szczegółowość, kontekstowość, interpretacyjność, międzykulturowa perspektywa. Były one wynikiem i widzenia, i patrzenia ${ }^{1}$, i zadawania pytań, a także podtrzymywania czujności w praktyce nauczycielskiej.

Bogusław Śliwerski (2017: 17), wypowiadając się o pedagogice ogólnej, zwrócił uwagę na jej rolę (w rewolucji postindustrialnej) w budowaniu cywilizacji humanum, w której „pomożemy dzieciom i młodzieży, ale i światu dorosłych czy osób starszych rozwiązywać ich codzienne problemy w realu, z jednoczesnym zrozumieniem sensów zachodzących w wirtualnym świecie".

Można się zgodzić z konstatacjami Agaty Cudowskiej:

Wydaje się, że wpisanie twórczości w świadomość aksjologiczną nauczyciela, przyjęcie przez niego hermeneutycznej perspektywy w przeżywaniu wychowawczego doświadczenia oraz stosowanie strategii interpretacyjnych podczas towarzyszenia uczniowi w zdobywaniu mądrości są istotnymi warunkami urzeczywistniania wizji twórczej szkoły jako szkoły przyszłości. (Cudowska 2014: 210)

Cudowska proponuje w związku z tym cztery aspekty wychowania: przez działalność kulturotwórczą, przez twórczą pracę, przez zmianę oraz przez samorozwój i autokreację (tamże: 213). Wspólną płaszczyzną dla współuczestników „wielopodmiotowego dialogu edukacyjnego”, czyli uczniów, nauczycieli i autorów, jest np. „zaangażowanie w codzienność, oznaczające także jej twórcze przeżywanie i dostrzeganie niezwykłości tam, gdzie inni widzą tylko zwyczajność. Oryginalność, osobliwość rzeczy, leży bowiem nie tylko w ich naturze, ale także w sposobie patrzenia na nie" (tamże: 209). Chodzi więc również o wykorzystywanie wyobraźni. Za Deweyem autorka powtarza, że „wyobraźnia obecna jest wszędzie tam, gdzie to, co jest znane, nabiera cech nowości, staje się zagadkowe oraz intrygujące" (tamże: 121). Przytoczmy jeszcze za Cudowską (i Frommem) składniki postawy twórczej, na którą wskazują: widzenie i doświadczanie, świadomość i wrażliwość, dziwienie się, ciekawość i koncentracja, doświadczanie „ja” i „jaźni”, akceptacja konfliktów i napięć, odwaga bycia innym oraz wiara w rzeczywistość własnego doświadczenia (tamże: 95).

1 Widzenie - za Wolcottem - to przypisywanie znaczeń kulturowych obserwowanym zjawiskom, natomiast patrzenie to obserwacja, wywiad, pytania, dane (Červinkovà 2013: 123-137). 
Jan Polakowski, dydaktyk literatury, przedstawiając idee podmiotowej dydaktyki, pisał m.in. o doświadczeniach literackich², na które składają się: motywacje, programy poznawczo-percepcyjne i wzory zachowań. Sukces dydaktyczny definiował następująco: „[...] związany jest z ukształtowaniem u wychowanka przekonania, że literatura (i wiedza o niej) jest do czegoś potrzebna, odgrywa jakąś istotną rolę w życiu osobistym" (Polakowski 1998: 15). Ponadto: "Człowiekowi, który w pozaszkolnym życiu nie będzie szukał kontaktów z literaturą, bo nie będzie wiedział, co one mogą mu dać, na nic zda się rozbudowana wiedza o literaturze i umiejętności analityczno-interpretacyjne" (Polakowski 1993: 29).

Nurt antropocentryczno-kulturowy Polakowski uznawał za drogę tworzenia teorii kształcenia literackiego (obok dydaktyki ogólnej, prakseologii i teorii literatury) i wskazywał dwa filary nurtu: „1) skupienie uwagi na podmiocie uczącym się literatury (języka) i 2) włączenie w obręb zainteresowań dydaktyki współczesnego środowiska kulturowego jako czynnika wpływającego na przebieg kształcenia literackiego i językowego" (Ogłoza 2001: 47-61). Zauważmy, że Polakowski nie pisze jeszcze o kształceniu literacko-kulturowym czy kulturowo-literackim. Dodajmy, że wskazany przez badacza nurt określany był też mianem: dydaktyka podmiotowa, szkoła na miarę ucznia, „najpierw człowiek” (Maria Jędrychowska) czy „z uczniem pośrodku” (Tadeusz Patrzałek).

Zenon Uryga (1996) w Godzinach polskiego... rozważał cztery problemy: rolę wyobraźni projektującej, prakseologiczne modelowanie lekcji, przemyślany kurs wiedzy o literaturze oraz antropocentryczną orientację lekcji, kiedy to uwaga przeniesiona jest z dzieła literackiego na ucznia poznającego literaturę, stawiającego w drodze ku interpretacji „kroki” na swoją miarę i zadającego sobie pytania: Czym jest dla mnie literatura? Po co czyta się we „własnym imieniu”?

Rację ma Krzysztof Koc (2018), że nadal warto uwzględniać teorię Bożeny Chrząstowskiej (wprowadzania pojęć teoretycznoliterackich) czy teorię postaw czytelniczych Jana Polakowskiego, dokonując jednak aktualizacji lub modyfikacji obu koncepcji. Autor znakomitej książki o reportażach przypomniał także prace Zenona Urygi (refleksja nad uczniem jako podmiotem procesu nauczania; odbiór dzieła literackiego; sens i prakseologiczny ład działań edukacyjnych), Marii Jędrychowskiej (spotkanie szkolnej rzeczywistości z uniwersytecką refleksją) i Zofii Agnieszki Kłakówny (m.in. myślenie kontekstowe). Formułując założenia metodyki koncepcyjnej, zwrócił uwagę na "metodyczną refleksję”,

2 Por. Michał Paweł Markowski (2005: 16-25) o doświadczeniu: „Kategoria doświadczenia [...] jest podstawową kategorią antropologiczną, która opisuje człowieka zanurzonego w życiu i starającego się o tym życiu powiedzieć coś innym po to, by oni także mogli je zrozumieć". 
która „przekładałaby się na innowacyjną, funkcjonalną, interesującą, celową i twórczą dydaktyczną propozycję" i dodał, że "bez poszanowania podmiotowości nauczyciela i ucznia trudno myśleć o jakościowej zmianie procesu kształcenia" (Koc 2015).

$\mathrm{O}$ antropocentryzmie w kształceniu językowym pisali m.in. Halina Wiśniewska (2016: 29-42) i Edward Polański (w zakresie ortografii). Wiśniewska podkreśla konieczność zwrócenia uwagi na konkretnego ucznia w określonej roli językowej, na rozwijanie uczniowskiej kompetencji językowej, na jego umiejętności wyrażania uczuć i emocji, myślenie stereotypami oraz stosunek do siebie, bliskich, obcych, innych, upośledzonych itp. (tamże: 35), a także wdrażanie do refleksji lingwistycznej. Polański, proponując podmiotowe nauczanie ortografii, zalecał wykorzystanie wiedzy psychologicznej o uczeniu się, do którego zaangażowane są zmysły i w którym odwołuje się do funkcjonowania obu półkul mózgowych oraz stosuje wizualizację (Polański i Rychlik 2002: 19-206).

W badaniach językoznawczych zdaniem Andrzeja Sitarskiego (2016: 419425) ważna jest diada człowiek - język: „Zasada antropocentryzmu w językoznawstwie udowadnia, że osiągnięcie adekwatnego pojęcia na temat istoty języka jest możliwe tylko w wypadku zbadania istoty człowieka uświadamiającego sobie samego siebie, swoje miejsce w świecie, a także swoją rolę w działaniach praktycznych”, czyli dokonuje się „analizy człowieka w języku i języka w człowieku”.

Zofia Agnieszka Kłakówna (2018), wielka reformatorka nauczania języka polskiego na wszystkich poziomach dzięki redagowanej i współtworzonej przez siebie serii „To lubię!”, pisząc o szkole zasługującej na miano szkoły XXI wieku, sformułowała dziesięć postulatów z myślą o dyskusji nad kształtem współczesnej edukacji polonistycznej. Stanowczo stwierdziła: „Obowiązkowa, podstawowa, powszechna, ogólna edukacja szkolna ma mieć »nacechowanie humanistyczne«, tj. warunki poznania organizować z perspektywy antropologicznej, w rozumieniu zarówno »antropologii filozoficznej«, jak i »kulturowej «" (tamże: 257). Inne postulaty dotyczyły: ciekawości, stawiania pytań i krytycznego myślenia, samodzielnej konceptualizacji świata czy odpowiedzialności za własne decyzje i wybory; samopoznania i samorozumienia, czyli budowania tożsamości; wolności od ideologicznej indoktrynacji; modyfikacji programów; celów edukacji językowej (narzędzie kultury, kreacji obrazu świata i komunikacji, obserwowane w działaniu); indywidualizacji; egzaminów wstępnych zamiast testów końcowych.

Elżbieta Kram-Mikoś (2009), interpretując liryki obecne w programie liceum, zastanawia się także nad empatią. Ustaliła, że pojęcie na gruncie psychologii oznacza wrażliwość zmysłową i emocjonalną, reaktywność poznawczą i wyobraźnię; łączy się ono z pokorą, życzliwością, taktem, delikatnością i subtelnością. Na gruncie socjologii empatia oznacza wspólnotę, solidarność 
międzyludzką i altruizm. Natomiast etyka wprowadza do refleksji nad empatią takie wątki, jak: partnerstwo, zrozumienie, neutralność, tolerancja, wolność, życzliwość, akceptacja oraz dialog.

Piotr Kołodziej wydał niedawno rozprawę o malarstwie w edukacji polonistycznej. To publikacja bardzo interesująca, tak pod względem teoretycznym, jak i praktycznym. Autor wykorzystał w niej wartościowe projekty własne oraz wizualne i wychowawcze efekty zajęć dydaktycznych w krakowskim liceum, odzwierciedlające jego fascynację sztuką Vermeera. Na początku pracy użył dwóch terminów: antropologiczny i antropocentryczny, a w innym miejscu przytoczył znakomite wyjaśnienie podstawy antropologicznej w edukacji; cytat zaczerpnął z książki Janusza Waligóry, który z kolei pisał o wspólnym, kierowanym przez Kłakównę, projekcie „To lubię!”. Waligóra napisał:

[...] interpretacja dzieła nie jest głównym, samoistnym ani ostatecznym celem realizowanym na lekcji języka polskiego. W ogóle dzieło nie jest najważniejsze. Najważniejsze jest rozpoznawanie swego człowieczeństwa w wytworach kultury stanowiących o jakości, sensie i treści kondycji ludzkiej - w wymiarze indywidualnym i uniwersalnym. (cyt. za: Kołodziej 2018: 110)

Marek Pieniążek postuluje wprowadzenie do szkolnej humanistyki antropologicznych modeli czytania. Uważa, że szkolne czytanie i interpretowanie nie może być tylko sytuacją ograniczoną do dwuwymiarowej płaszczyzny tekstologicznej, ale w trosce o elementarny pragmatyzm nauczania powinno stać się sytuacją kulturowo-egzystencjalną, wykraczającą poza pytania o literackość ku ogólnokulturowym diagnozom. W tej perspektywie ważna jest dla Pieniążka konstelacja historyczno-kulturowa, z której pochodzi dzieło, biografia autora, zestaw jego doświadczeń, zapatrywań, urazów, społecznych okoliczności i ściśle osobistych uwarunkowań twórczości. Istotny jest bohater utworu jako źródło wiedzy o pragmatycznych wymiarach ludzkiej egzystencji, a także umiejętność osadzenia właściwości dzieła w szerokim kontekście kulturowym, bez wzdragania się przed odkrywaniem kontekstów politycznych. Cenna jest umiejętność tworzenia nowych, dobrze uargumentowanych i rzetelnych interpretacji, odwołujących się do bieżących doświadczeń ucznia (zob. np. Pieniążek 2008: 139-158).

Jeśli chodzi o związki dydaktyki polonistycznej ze współczesnymi metodologiami, inspirujące są prace Anny Ślósarz (2018: 139-156), Anny Janus-Sitarz (2009) oraz Anny Włodarczyk (2014). Wszystkie autorki referują najważniejsze rozprawy teoretycznoliterackie, formułują wnioski dydaktyczne, a przede wszystkim przedstawiają zastosowanie omawianych kwestii w interpretacjach i scenariuszach lekcyjnych, wybierając głównie współczesne polskie powieści. 
Anna Ślósarz w tabelarycznym zestawieniu zapisała po lewej stronie dziesięć nurtów we współczesnej humanistyce, a po prawej - dopisała najważniejsze działania w dydaktyce polonistycznej. Wymieniła kolejno: interdyscyplinarność, intertekstualność, zwrot afektywny, zwrot performatywny, posthumanistykę, teorię aktora-sieci, zwrot ikoniczny, wirtualność, studia nad pamięcią, realizm traumatyczny oraz poezję uważną.

Anna Janus-Sitarz, łącząc dyskurs naukowy z dydaktycznym, pokazała, jak można w edukacji polonistycznej interpretować współczesną prozę z wykorzystaniem trzech metodologii: hermeneutyki, dekonstrukcjonizmu oraz intertekstualizmu.

W książce Anny Włodarczyk znalazło się dziesięć modeli lektury charakterystycznych dla różnych typów interpretacji etycznej, które nawiązują do etyki (pre)ontologicznej Martina Heideggera, Emanuela Levinasa i Józefa Tischnera, do etyki postmodernistycznej Zygmunta Baumana, Michela Foucaulta, Jacques'a Derridy oraz Richarda Rorty'ego oraz do etyki hermeneutycznej Hansa-Georga Gadamera, Paula Ricoeura i Gianniego Vattimo. Są to następujące modele interpretacji etycznych: projekt myślenia, odpowiedzialność wobec inności, dialog, niepewność, introspekcja, kontrasygnatura, wrażliwość, empatia, doświadczenie i pluralizm.

Z kolei Małgorzata Chrobak i Katarzyna Wądolny-Tatar (2018: 240-241) $\mathrm{w}$ artykule Nowoczesna literatura polska dla najmłodszych w perspektywie kulturowej teorii literatury wymieniły sześć zagadnień istotnych dla edukacji polonistycznej, a mianowicie: literatura wobec sztuk wizualnych; cielesność i tematy tabu, idące w stronę afektu, intensywnego przeżycia zarówno wpisanego w tekst, jak i wywoływanego u odbiorcy w trakcie czytania; geopoetyka w tekstach dla najmłodszych; historia, pamięć, codzienność w ich wzajemnych filiacjach oraz biograficznych (re)konstrukcjach; zwierzęta, zwierzęcość, ekologia (niektóre problemy „studiów nad zwierzętami” / animal studies); inność, etniczność, wielokulturowość jako aspekty tematyczno-konstrukcyjne utworów dla dzieci. Do tej listy tematów warto by dodać: rzeczy, rośliny, ptaki, kolekcje muzealne, narracje oraz wielozmysłowość.

Rozważając koncepcję pedagogiki nadziei w obrębie pedagogiki sytuacyjnej, Tadeusz Sławek (2017: 13) napisał: „Uczyć się to nie przyswajać sobie wiedzę, fakty i dane, ale komponować ze zdarzeń losu i przypadków konstelacje, a tego zadania rozum i wyobraźnia muszą podjąć się wspólnie”. Treść tego zdania o tym, że nie jesteśmy bezwolni, ale też nie mamy pełnej mocy sprawczej oraz że istnieje świat nie-ludzki - z pewnością mogłaby znaleźć się w podstawowych założeniach antropologicznych dydaktyki polonistycznej. Pedagogika, o której pisze Sławek, nie jest tylko pedagogiką nadziei, lecz także pedagogiką 
gościnności i tragicznej wizji świata, przebudzenia i wstrząsu. Poniżej przytaczam kilka ważnych cytatów: „Nadzieja jest szczególną gęstością, szczególnym stanem skupienia myślenia” (tamże: 17); „»Mogę« nie jest tożsame z »muszę«, bowiem etyka poucza mnie o istnieniu sfery wrażliwości innych osób, którym winny jestem rozmowę, zapytanie, próbę uzgodnienia moich racji z ich racjami. $[\ldots]$ wiem, że »nie muszę« wszystkiego, co »mogę« [...], »nie mogę« wszystkiego, co »muszę«” (tamże: 18); „Nadzieja to podróż bez gwarancji dotarcia do miejsca przeznaczenia. [...] nic nie ma bardziej obcego nadziei niż swojskość i domowość” (tamże: 19); „Nadzieja tworzy wspólnotę człowieka i zwierzęcia. Jest zwierzęco-ludzka” (tamże: 22); „[Nadzieja] [j]est formą myślenia tworzącą solidarność [...]" (tamże: 23).

Wskazałam powyżej na wiele opracowań dotyczących antropologicznych założeń teorii i badań empirycznych w przekonaniu, że można w nich szukać inspiracji, wskazówek, przemyśleń i konkretnych rozwiązań dla dydaktyki polonistycznej. W przeglądowym artykule pragnę spopularyzować wśród dydaktyków języka polskiego tezy badaczy reprezentujących inne dyscypliny humanistyczne oraz przypomnieć najważniejsze prace z nurtu antropologiczno-kulturowego dyscypliny macierzystej. Ze względu na ogromną liczbę publikacji i zawartych w nich problemów oraz sposobów ujęcia teorii i badań empirycznych moim zamierzeniem nie jest ani wyczerpanie tematu, ani dokonanie pełnej klasyfikacji zagadnień. Dokonałam wyboru subiektywnego, kierując się przydatnością omawianych tekstów dla antropologicznie zorientowanej dydaktyki literatury, kultury i języka, która wciąż się rozwija, pogłębiając rozumienie procesów czytelniczych i dydaktycznych (zob. m.in. Koziołek 2006, 2016). Poniżej zamieszczam kilka przykładów tekstów kultury, które mogłyby wystąpić w szkolnej praktyce polonistycznej i być przeczytane, zinterpretowane lub wykonane.

Przykład 1. Malarstwo Katarzyny Karpowicz (ur. 1985). Warto pokazywać uczniom obrazy malarki z Krakowa, zebrane w kilkadziesiąt cykli (http://katarzynakarpowicz.pl). Punktem wyjścia można uczynić internetową stronę czy prezentację na Facebooku, a następnie przejrzeć katalogi z kilku wystaw. Malarka zachwyca wyobraźnią, barwami, nastrojem i refleksją, kontekstami literackimi (np. motywy sadu i proza Wiesława Myśliwskiego), teatralnymi i filmowymi, a swoje dzieło z dużą świadomością interpretuje, także w kontekście biografii.

Jeden z obrazów Karpowicz, Idee (http://katarzynakarpowicz.pl/wp-content/ uploads/2017/03/KatarzynaKarpowiczPortfolio.pdf), przedstawia nierealną, baśniową, wizyjną scenę jak ze snu. Spod ziemi czy z otworu w dachu wyłania się, korzystając z drabiny, dziewczynka, która „wysyła” lub odbiera myśli, a one na obrazie wyglądają jak jakieś świetlne obiekty, przypominają gwiazdy 
lub bańki mydlane ${ }^{3}$. Piękna zieleń na powierzchni czegoś kontrastuje z czernią dziwnej przestrzeni pod spodem i z cieniem, w którym pozostaje dziewczynka. Dostrzegam nawiązania do mitu o Orfeuszu i Eurydyce lub Demeter i Korze, a także do Pastereczki i kominiarczyka Andersena. Zauważam też teatralność sytuacji - zapadnię w scenie, spod podłogi ktoś się wyłania, a bańki mydlane są jak w Balladynie sprzed lat w reżyserii Adama Hanuszkiewicza.

Cykl Baseny oznacza np. powrót do początków świata czy do narodzin; dostrzegamy symbolikę podświadomości, a w postaciach pływaków - lekkość, wolność, swobodę, a może i walkę (sylwetka pływaka ułożona jak strzała), szybkość, harmonię. Dostrzegamy odrealnienie sytuacji (błękit wody i prawie naga, uproszczona sylwetka człowieka). Być może człowiek jest samotny, odizolowany, szuka zapomnienia czy ucieczki w innym, podwodnym świecie, a doznania cielesne i wysiłek fizyczny przynoszą uspokojenie pragnień i ukojenie tęsknoty. $\mathrm{Z}$ wypowiedzi artystki wiemy, że cykl odzwierciedla fakty i emocje nastolatki podczas śmiertelnej choroby ojca.

Przykład 2. Liryk Adama Zagajewskiego (1999) - apoteoza czynności pływania, która zostaje porównana do modlitwy.

Lubię pływać w morzu,

[...]

Pływanie jest jak modlitwa:

dłonie łączą się i rozdzielają,

łączą i rozdzielają,

nieomal bez końca.

Przykład 3. Anna Arno i fragment Tego kraju - opis cielesnych doznań $\mathrm{w}$ momencie zanurzenia w Bałtyku, zatracenie się w wodzie, zapomnienie się, skupienie na tym, co wywołuje radość, że się jest, co zachwyca w morzu i jaka jest miłość do żywiołu.

Kiedy stałam na brzegu, a piana lizała mi stopy, nie mogłam sobie wyobrazić, że wejdę głębiej. Chroniła mnie koperta ubrania, nagrzanego w cierpliwym czerwcowym słońcu. [...] Tak więc wchodziłam w Bałtyk [...]. Bałam się zimnej wody

3 O bańkach pisała w swoim studium Aneta Grodecka (2013). Motyw bańki występuje w interesującej mini-opowieści Stanisława K. Stopczyka (1974). Celestyn, dziwak i mieszkaniec drzewa, chciał się podzielić radością, że udało mu się po 50 latach stworzyć ogromną bańkę mydlaną, ale wzbudzał nieufność, wrogość, niezrozumienie u ludzi, do których dotarł. Okazało się po jego powrocie do Kalamburii, że jednak ważna była opowieść o tworzeniu i pięknie, a nie sam obiekt, który po drodze uległ zniszczeniu. 
i pragnęłam jej - żeby mocniej poczuć, że jestem, kiedy dotknie skóry, zwęzi naczynia, poruszy krew. [...] Najtrudniej jest zanurzyć głowę - ta chwila jest jak zejście lodowca. Przecież postanowiłam się schłodzić, oddzielić rzeczywistość od wyobraźni. Dlatego wkładam głowę pod lód i poza tym nic nie istnieje, ani mój strach, ani moja wyobraźnia. [...] Dałeś mi ciało, i cóż ja z nim zrobię. Skąpię je w morzach, żeby coś poczuło - głód i ból, szczęście i pragnienie. [...] Po trzydziestu kilometrach czuję każdy mięsień, jak się porusza staw biodrowy, czuję ciężar ciała, które noszę ze sobą. (Arno 2018: 84-87)4

Przykład 4. Książka Krzysztofa Środy, której tytuł Srebro ryb nawiązuje do haiku Basho ${ }^{5}$, mogłaby okazać się interesującą lekturą z wielu względów: wędkarskie tematy; wartościowe, inspirujące fragmenty opisowe (okoliczności pogodowe, np. szron; szczegóły wyglądu, piękno i różnorodność ryb); elementy autobiograficzne, w tym śmierć przyjaciela, własna twórczość i lektury (np. Jerzy Putrament czy Ota Pavel); fragmenty filozoficzne (o tworzeniu, głębi i tajemnicy, widzeniu i widzialności czy istnieniu bez bycia dostrzeganym); kulinaria.

Przykład 5. Adam Zagajewski (2019: 26) nakłaniał w bardzo głośnym liryku pt. Spróbuj opiewać okaleczony świat do odczuwania radości z drobiazgów mimo wielu tragicznych zdarzeń. W nowo wydanym tomie znakomitego poety pt. Prawdziwe życie znajduje się liryk Krótkie chwile, pełen zachwytu nad tym, co może się zdarzyć pięknego i wartościowego, ale też wątpliwości, żalu czy niepokoju, że takie sytuacje trwają krótko i występują jedynie od czasu do czasu. Takie przemyślenia zawarte zostały w powtarzanym pytaniu („To ma być życie?”) i powtórzonej konstatacji oraz w synonimach chwil i epitetach (krótkie chwile, nieliczne dni, momenty, rzadkie godziny). W liryku z tego samego tomu poeta wskazuje na możliwość odczuwania litości wobec świata przyrody:

\author{
Jest tylko litość - \\ Dla ludzi, zwierząt, drzew, obrazów, \\ Istnieje tylko litość, \\ Zawsze spóźniona.
}

4 Opis pochodzi z fragmentu Dotyk, który rozpoczyna się od rejestracji wrażeń dotykowych i węchowych związanych z tkaninami. Dłoń dotyka tkanin, a tkaniny dotykają ciała. Już tylko krok do refleksji o nagości i ubraniu oraz do opisu doznań cielesnych - zanurzenia w chłodnej morskiej wodzie Bałtyku, ukąszenia owada, bólu mięśni po trzydziestu kilometrach marszu.

5 „Lśni w wodorostach srebro ryb, / lecz dotknięte / zgaśnie na pewno” (Środa 2019). 
Przykład 6. Poezja i proza Urszuli Zajączkowskiej. Uwagę zwraca tu zarówno twórcza wyobraźnia poetki, jak i wiedza czy umiejętności botaniczki. Zajączkowska proponuje nie tyle dyskurs naukowy (szkiełka i oka) lub sentymentalny - jako wrażliwa, doświadczająca obserwatorka przyrody, ile dyskurs o współ-byciu w świecie żywych istot (mających swoją historię, produkujących tlen, podatnych na zranienia, podlegających rytmowi życia i śmierci, narodzin i umierania). Jak to ujęła Katarzyna Szopa (2019: 148): „Nie pyta o to, czy i gdzie leży granica między człowiekiem a rośliną, lecz o to, jak żyć z innymi we wspólnym świecie ludzi i nieludzi".

Warto posłuchać rad Zajączkowskiej, która w wywiadzie "jesiennym" zachęca do obserwowania przyrody przygotowującej się do zimy i kolejnej wiosny, a także do skupienia uwagi na detalu przyrodniczym i do stawiania pytań problemowych, np. dlaczego jesienne liście przybierają tyle barw („Te wszystkie kolory były wcześniej w liściu, tylko przysłonięte chlorofilem”), oraz do dotykania i rysowania. Biolożka i antropolożka namawia:

[...] do obserwowania wszystkiego, co blisko, a najlepiej tego, co pozornie jest najmniej ciekawe. Do przyglądania się tej przestrzeni, która dla człowieka jest tylko tłem. Zwyczajne patrzenie w koronę drzewa i śledzenie dróg jej konarów, $\mathrm{w}$ trawniki tuż pod nogami, w chwasty zza krawężnika, w suchy badyl [...] przyglądałabym się zwyczajnemu. (Kozak 2019: 29; zob. także: Kubisiowska 2019: 64-68)

Zajączkowska oryginalnie i wręcz brawurowo opisuje np. pokrzywę, przedstawiając i udowadniając analogię z kotem (tytuł rozdziału Kociak), a przy okazji przekazując porcję wiedzy botanicznej i zoologicznej:

[...] kot może być blisko, ale jak on chce [...] może domagać się dotyku, gdy będzie tego potrzebował i do czasu, który on też ustala. [...] Bo kot przede wszystkim wymaga od nas elementarnego szacunku i uznania. To samo pokrzywa.

Pokrzywa to apofit, czyli istota, która jak kot, żyć może na brudno, krwiście i dziko, ale może być też i bliżej człowieka [...] porasta zatem krawędzie ludzkich szlaków gęstym łanem, całym w szorstkości, najeżonym, krok w krok, wciąż wyglądając, dokąd idziemy. Wciąż po swojemu. [...] Jesienią zmieniają się w drzemiące zawiniątka zdrewniałych kłączy o grubym futrze, z ukrytymi pod ściółką pąkami, pełnych słodkich albo bardzo tłustych snów. Zimą pokrzywa i kot śpią jeszcze dłużej niż zwykle. [...] Pokrzywa kłuje [...]. Ostrymi jak koci pazur włoskami. [...] To jest ten moment, kiedy pokrzywę zauważasz w całej okazałości i kiedy doświadczasz wściekłości kota. [...] kwiaty żeńskie są kociobiałe i puchate. [...] Nastroszy futro, białe puchate znamiona wystawi na działanie wiatru i gdy 
to wszystko się już zdarzy, najzwyczajniej zawiąże nasiona, wypije mleko, zwinie się w kłębek i pójdzie spać. (Zajączkowska 2019: 223-233)

Wrażliwość i dociekliwość badawcza objawia się np. w takim krótkim fragmencie, któremu towarzyszy zdjęcie miejskiej drogi: „Wielce niezagospodarowana kwadratowa dziura w tym betonie. Ileż tu się marnuje! Studnia przestrzeni, a tylko kilka liści. Gdybyśmy umarli wszyscy, za kilkaset lat mogłaby tu być puszcza" (tamże: 205). Dodam, że rośliny pojawiają się w przestrzeni miasta na ruinach - przykładem mogą być resztki zawalonej kamienicy na ulicy Chopina w Katowicach, gdzie w miejscu katastrofy rosną na cegłach drzewka (samosiejki).

Powtórzę za Anną Śliwą (2018: 512) zdanie napisane w kontekście prozy Mirona Białoszewskiego, które można odnieść też do innych tekstów: „Zauważanie w tym, co zwykłe, odbicia sztuki staje się dodatkowym zmysłem, rodzajem umiejętności, którą można określić jako wrażliwość czy - po Norwidowsku - »czułość«".

Przykłady (inne). Warto nawiązywać na lekcjach literackich do współczesnych tekstów, w których pojawia się krajobraz (Bell 2015; Eichstaedt 2013; Sławek 2014) oraz świat natury: ptaki (Hughes 1995; Łubieński 2016), ryby (Środa 2012), drzewa (de Fombelle 2008; Jerzyna 1972; Stempowski 2012; Ziółkowska 19886), owady (Łoziński 2008; Nawarecki 2017) i człowiek, który naturę obserwuje, chroni bądź bezmyślnie (okrutnie) w nią ingeruje, wnikliwie opisuje, zachwyca się nią, szuka dla niej miejsca w swoim życiu, tak aby więzi były silne i wielostronne (np. Książek 2015; Robiński 2017). Rozmawiając z uczniami o ich doświadczeniach obcowania z naturą, o przeżyciach i przemyśleniach, można podpowiedzieć tytuł, wskazać wywiady w czasopismach oraz internecie, polecić spotkania autorskie, a przede wszystkim podjąć dyskusję wokół problemów, które pojawiają się w kręgu ekokrytyki (zob. Skurtys 2017: 203-219), geopoetyki, animal studies, czyli w różnych nurtach współczesnej humanistyki.

6 Zob. także zapis działań artystycznych Cecylii Malik. 


\section{BIBLIOGRAFIA}

\section{Literatura}

Arno, A. (2018). Ten kraj. Kraków: Wydawnictwo Literackie.

Bell, D. (2015). Nauka poza murami szkoły (Expeditionary Learning) - autentyczna edukacja w XXI wieku. W: G. Mazurkiewicz (red.), Uczaca się szkoła. Od rozwoju jednostek do rozwoju wspólnoty (s. 181-196). Warszawa-Kraków: Wydawnictwo Uniwersytetu Jagiellońskiego.

Chrobak, M., Wądolny-Tatar, K. (2018). Nowoczesna literatura polska dla najmłodszych w perspektywie kulturowej teorii literatury. W: J. Tambor (red.), Polonistyka na poczatku XXI wieku. Diagnozy. Koncepcje. Perspektywy (T. 1: Literatura polska i perspektywy nowej humanistyki; s. 240-241). Katowice: Wydawnictwo Uniwersytetu Śląskiego.

Cudowska, A. (2014). Kształtowanie twórczych orientacji życiowych w procesie edukacji. Pobrane z: https://repozytorium.uwb.edu.pl/jspui/bitstream/11320/2722/1/ Agata\%20Cudowska_Kszta\%C5\%82towanie\%20tw\%C3\%B3rczych\%20orientacji\%20\%C5\%BCyciowych\%20w\%20procesie\%20edukacji.pdf [dostęp: 7.10.2019].

Červinkovà, H. (2012). Badania w działaniu i zaangażowana antropologia edukacyjna. Teraźniejszość - Człowiek - Edukacja, nr 1(57), 7-18.

Červinkovà, H. (2013). Etnografia edukacyjna i badania w działaniu - z warsztatu kształcenia nauczycieli. Forum Oświatowe, nr 1(48), 123-137.

Drozdowicz, J. (2018). Antropologia edukacji jako odpowiedź na wyzwania nowej wielokulturowości. Forum Oświatowe, nr 30(2), 135-151.

EASA (2015). Dlaczego antropologia jest istotna. Pobrane z: https://www.easaonline. org/downloads/publications/policy/EASA\%20policy\%20paper_PL.pdf [dostęp: 10.09.2020.

Eichstaedt, J. (2013). Antropologia dla muzeum, muzeum dla antropologii. Pobrane z: https://depot.ceon.pl/bitstream/handle/123456789/6333/Antropologia_dla_ muzeum_muzeum_dla_antropologii.pdf?sequence $=1$ \&isAllowed=y [dostęp: 7.10.2019].

Filipowicz, P. (2012). Antropologia jako doświadczenie człowieka. Studia Kulturowe, nr 3, 44-56.

Fombelle, T. de (2008). Tobi. Życie w zawieszeniu. Kraków: Społeczny Instytut Wydawniczy Znak.

Gołębniak, M. (2017). Antropologia i etnografia edukacyjna - na pograniczu dyscyplin. Forum Oświatowe, nr 30(2), 45-60.

Grodecka, A. (2013). Bańka mydlana. Artefakt w przestrzeni pamięci. Poznań: Poznańskie Studia Polonistyczne.

Hughes, T. (1995). Pieśni czterech pór roku. Poznań: Zysk.

Janus-Sitarz, A. (2009). Przyjemność i odpowiedzialność. O praktykach czytania literatury w szkole. Kraków: TAiWPN Universitas.

Jerzyna, Z. (1972). Wśród drzew. Warszawa: Nasza Księgarnia. 
Kłakówna, Z.A. (2018). Szkoła na XXI wiek. W: M. Kwiatkowska-Ratajczak, B. Przymuszała (red.), Polskie czytanie Wschodu. Kultura - autobiografia - edukacja (s. 257). Poznań: Wydawnictwo PSP.

Koc, K. (2015). Metodyka koncepcyjna - edukacyjna wartość narzędzi polonistycznych (analityczno-interpretacyjnych). Polonistyka. Innowacje, nr 1, 121-132, DOI: https:// doi.org/10.14746/pi.2015.1.1.10.

Koc, K. (2018). Software w szkolnym kształceniu polonistycznym, czyli o znaczeniu aktualizacji teorii dydaktycznych. Polonistyka. Innowacje, nr 7, 71-83, DOI: http:// dx.doi.org/10.14746/pi.2018.1.7.6.

Kołodziej, P. (2018). Dwadzieścia pięć twarzy dziewczyny z perła. Praktyka czytania dziet malarskich $w$ procesie ksztatcenia kulturowo-literackiego. Kraków: Oficyna Wydawnicza Impuls.

Kozak, A. (2019). Rośliny to wiedzą na pewno będzie wiosna. Z Urszulą Zajączkowską rozmawia Aga Kozak. Gazeta Wyborcza. Magazyn Świateczny, 21-22 września, 29.

Koziołek, K. (2006). Czytanie z innym: etyka, lektura, dydaktyka. Katowice: Wydawnictwo Uniwersytetu Śląskiego.

Koziołek, K. (2016). Czas lektury. Katowice: Wydawnictwo Uniwersytetu Śląskiego.

Kram-Mikoś, E. (2009). Lekcje empatii. Czytanie poezji dwudziestowiecznej w liceum: literatura - psychologia - dydaktyka. Kraków: Wydawnictwo Naukowe Uniwersytetu Pedagogicznego.

Książek, M. (2015). Droga 816. Białystok: Fundacja Sąsiedzi.

Kubisiowska, K. (2019). Fasola patrzy na księżyc. Tygodnik Powszechny, 7 lipca (3652), 64-68.

Łoziński, M. (2008). Bajki dla Idy. Kraków: Społeczny Instytut Wydawniczy Znak.

Łubieński, S. (2016). Dwanaście srok za ogon. Wołowiec: Wydawnictwo Czarne.

Markowski, M.P. (2005). Antropologia, humanizm, interpretacja. Teksty Drugie, nr 5, 16-25.

Nawarecki, A. (2017). Requiem na lepie. O Musze Juliana Tuwima. Pobrane z: https:// repozytorium.uwb.edu.pl/jspui/bitstream/11320/8339/1/A_Nawarecki_Requiem_ na_lepie_O_Musze_Juliana_Tuwima.pdf [dostęp: 7.10.2019].

Ogłoza, E. (2001). Fundamenty teorii kształcenia literackiego w dziele Jana Polakowskiego. W: B. Kędzi-Klebeko, A. Ciciak (red.), Wczoraj i dziś edukacji polonistycznej (s. 47-61). Szczecin: Uniwersytet Szczeciński.

Pieniążek, M. (2008). Poetyka kulturowa dla szkoły: dydaktyka polonistyczna wobec wyzwań antropologii literatury. Annales Universitatis Paedagogicae Cracoviensis. Studia Historicolitteraria, nr 8, 139-158.

Polakowski, J. (1993). O sytuacji we współczesnej dydaktyce literatury (w poszukiwaniu podstaw teorii kształcenia literackiego). Z Teorii i Praktyki Dydaktycznej Języka Polskiego, t. 10, 7-32.

Polakowski, J. (1998). Idee dydaktyki podmiotowej w podstawowych problemach kształcenia literackiego (nurt antropocentryczno-kulturowy). W: Z. Uryga (red.), Podmiotowy wymiar szkolnej polonistyki. Materiaty z konferencji „Antropocentryczno-kulturowy nurt w kształceniu polonistycznym" (Kraków, 23-24 października 1995) (s. 5-32). Kraków: Wydawnictwo Naukowe WSP.

Polański, E., Rychlik, A. (2002). Podmiotowość w nauczaniu zintegrowanym ortografii. Nauczyciel i Szkoła, nr 3-4, s. 199-206. 
Robiński, A. (2017). Hajstry - krajobraz bocznych dróg. Wołowiec: Wydawnictwo Czarne. Rybska, E., Sajkowska, Z. (2015). Czym jest antropologiczna teoria dydaktyczna (ATD)? Pobrane z: www.researchgate.net/profile/Eliza_Rybska2/publication/280920663_ Czym_jest_antropologiczna_teoria_dydaktyki_ATD/links/55cb2f1508aeca747d6a13bf/Czym-jest-antropologiczna-teoria-dydaktyki-ATD.pdf [dostęp: 5.10.2019].

Sajdak-Burska, A. (2017). Paradygmat humanistyczny w dydaktyce akademickiej-utopia, konieczność, szansa. Pobrane z: https://ruj.uj.edu.pl/xmlui/bitstream/handle/ item/59858/sajdak-burska_paradygmat_humanistyczny_w_dydaktyce_akademickiej_2017.pdf?sequence=1\&isAllowed=y [dostęp: 6.10.2019].

Sikora, M. (2017). Współczesne rodzaje i konteksty praktycznego wykorzystania antropologii kulturowej w Polsce. Zeszyty Etnologii Wrocławskiej, nr 1(26), 143-167.

Sitarski, A. (2016). Paradygmat antropocentryczny jako kategoria lingwistyczna w badaniu obiektów językowych. Studia Rossica Posnaniensa, t. 41, 419-425, DOI: https:// doi.org/10.14746/strp.2016.41.38.

Skurtys, J. (2017). Zamiast Szymborskiej? Krystyna Miłobędzka i źródła współczesnej ekopoezji w Polsce. Przestrzenie Teorii, nr 28, 203-219.

Sławek, T. (2014). Adres i wędrówka. Szkic oikologiczny. Prace Komisji Krajobrazu Kulturowego, $\mathrm{nr}$ 24, 65-77.

Sławek, T. (2017). Edukacja jako tworzenie i podtrzymywanie kultury nadziei. Rocznik Pedagogiczny, t. 40, 9-24.

Stempowski, J. (2012). Ziemia berneńska. Warszawa: Fundacja Zeszytów Literackich. Stopczyk, S.K. (1974). Celestynie, a cóż to za dziwo? Kraków: Wydawnictwo Literackie. Szopa, K. (2019). Poetyckie archiwum roślinne: casus Urszuli Zajączkowskiej. Zagadnienia Rodzajów Literackich, t. 41(1), 143-150, DOI: http://dx.doi.org/10.26485/ ZRL/2018/61.1/10.

Śliwa, A. (2018). „Czułość wszystkiego”. Rola zmysłów w prozie i „Tajnym dzienniku” Mirona Białoszewskiego. W: J. Tambor (red.), Polonistyka na poczatku XXI wieku. Diagnozy, koncepcje, perspektywy (T. 1: Literatura polska i perspektywy nowej humanistyki; s. 499-514). Katowice: Wydawnictwo Uniwersytetu Śląskiego.

Śliwerski, B. (2017). Pedagogika nadziei. Prima Educatione, 13-19, DOI: https://doi. org/10.17951/pe.2017.1.13.

Ślósarz, A. (2018). Dydaktyka „nowej humanistyki”: szanse i nieuniknione zagrożenia. W: J. Tambor (red.), Polonistyka na poczatku XXI wieku. Diagnozy. Koncepcje. Perspektywy (T. 1: Literatura polska i perspektywy nowej humanistyki; s. 139-156). Katowice: Wydawnictwo Uniwersytetu Śląskiego.

Środa, K. (2012). Srebro ryb. Wołowiec: Wydawnictwo Czarne.

Środa, K. (2019). Srebro ryb. Wołowiec: Wydawnictwo Czarne.

Uryga, Z. (1996). Godziny polskiego. Z zagadnień ksztatcenia literackiego. Warszawa: PWN.

Wiśniewska, H. (2016). Antropocentryzm a kształcenie językowe. W: M. Karwatowska, L. Tymiakin (red.), Wokót edukacji polonistycznej w szkole. Teoria i praktyka (s. 29-42). Lublin: Wydawnictwo UMCS.

Włodarczyk, A. (2014). Etyka interpretacji tekstu literackiego. Postmodernizm, humanizm, dydaktyka. Kraków: Wydawnictwo Uniwersytetu Jagiellońskiego. 
Pobrane z czasopisma Annales N - Educatio Nova http://educatio.annales.umcs.pl Data: 26/04/2023 17:20:07

Zagajewski, A. (1999). Pragnienie. Kraków: Wydawnictwo a5.

Zagajewski, A. (2019). Prawdziwe życie. Kraków: Wydawnictwo a5.

Zajączkowska, U. (2019). Patyki, badyle. Warszawa: Wydawnictwo Marginesy.

Ziółkowska, M. (1988). Gawędy o drzewach. Warszawa: Ludowa Spółdzielnia Wydawnicza.

\section{Strony internetowe}

Katarzyna Karpowicz. http://katarzynakarpowicz.pl [dostęp: 10.05.2020].

Katarzyna Karpowicz. Portfolio. http://katarzynakarpowicz.pl/wp-content/uploads /2017/03/KatarzynaKarpowiczPortfolio.pdf [dostęp: 10.05.2020]. 